\title{
Sex-specific effects of prenatal stress on glucose homoeostasis and peripheral metabolism in rats
}

\author{
Paula J Brunton', Katie M Sullivan², David Kerrigan², John A Russell ${ }^{3}$, \\ Jonathan R Seckl ${ }^{2}$ and Amanda J Drake ${ }^{2}$ \\ 'Division of Neurobiology, The Roslin Institute and R(D)SVS, University of Edinburgh, Easter Bush Campus, \\ Midlothian, EH25 9RG, UK, \\ ${ }^{2}$ Endocrinology Unit, University/British Heart Foundation Centre for Cardiovascular Science, University of \\ Edinburgh, Queen's Medical Research Institute, 47 Little France Crescent, Edinburgh, EH16 4TJ, UK and \\ ${ }^{3}$ Laboratory of Neuroendocrinology, Centre for Integrative Physiology, University of Edinburgh, George Square, \\ Edinburgh, EH8 9XD, UK
}

\author{
Correspondence \\ should be addressed to \\ P J Brunton \\ Email \\ p.j.brunton@ed.ac.uk
}

\begin{abstract}
Glucocorticoid overexposure during pregnancy programmes offspring physiology and predisposes to later disease. However, any impact of ethologically relevant maternal stress is less clear, yet of physiological importance. Here, we investigated in rats the short- and longterm effects in adult offspring of repeated social stress (exposure to an aggressive lactating female) during late pregnancy on glucose regulation following stress, glucose-insulin homoeostasis and peripheral expression of genes important in regulating glucose and lipid metabolism and glucocorticoid action. Prenatal stress (PNS) was associated with reduced birth weight in female, but not male, offspring. The increase in blood glucose with restraint was exaggerated in adult PNS males compared with controls, but not in females. Oral glucose tolerance testing showed no effects on plasma glucose or insulin concentrations in either sex at 3 months; however, at 6 months, PNS females were hyperinsulinaemic following an oral glucose load. In PNS males, plasma triglyceride concentrations were increased, with reduced hepatic mRNA expression of $5 \alpha$-reductase and peroxisome proliferator-activated receptor $\alpha$ (Ppar $\alpha$ (Ppara)) and a strong trend towards reduced peroxisome proliferatoractivated receptor gamma coactivator $1 \alpha$ (Pgc1 $\alpha$ (Ppargc1a)) and Ppary (Pparg) expression, whereas only Pgc $1 \alpha$ mRNA was affected in PNS females. Conversely, in subcutaneous fat, PNS reduced mRNA expression of $11 \beta$-hydroxysteroid dehydrogenase type 1 (11 $\beta$ hsd 1 ), phosphoenolpyruvate carboxykinase (Pepck (Pck1)), adipose triglyceride lipase (Atgl) and diglyceride acyltransferase 2 (Dgat2) in females, but only Pepck mRNA expression was reduced in PNS males. Thus, prenatal social stress differentially programmes glucose homoeostasis and peripheral metabolism in male and female offspring. These long-term alterations in physiology may increase susceptibility to metabolic disease.
\end{abstract}

Journal of Endocrinology (2013) 217, 161-173

\section{Introduction}

Exposure to an adverse environment in utero, manifesting in a reduction in birth weight, is associated with a substantially increased risk of cardiometabolic disorders, neuroendocrine dysfunction and psychiatric disease in http://joe.endocrinology-journals.org DOI: 10.1530/JOE-12-0540
(C) 2013 Society for Endocrinology Printed in Great Britain
Published by Bioscientifica Ltd 
childhood and adulthood (Seckl \& Holmes 2007). Moreover, evidence from human studies indicate that prenatal stress (PNS) is associated with a greater risk for developing insulin resistance and type 2 diabetes later in life (Entringer et al. 2008, Li et al. 2012). One of the major mechanisms proposed to explain this link is prenatal glucocorticoid overexposure (Edwards et al. 1993). In rats, maternal stress, synthetic glucocorticoid administration or inhibition of $11 \beta$-hydroxysteroid dehydrogenase type 2 (11ßHSD2; the placental 'barrier' to maternal glucocorticoids that deactivates endogenous glucocorticoids) during late pregnancy results in offspring of low birth weight (Lindsay et al. 1996a, Benediktsson et al. 1997, Nyirenda et al. 1998, Welberg et al. 2000, Lesage et al. 2004, Brunton \& Russell 2010) that later develop glucose intolerance (Lindsay et al. 1996b, Nyirenda et al. 1998, Lesage et al. 2004), hypertension (Benediktsson et al. 1993, Lindsay et al. 1996a, Nyirenda et al. 1998), hyperactive hypothalamic-pituitary-adrenal (HPA) axis responses to stress and/or increased anxiety (Welberg et al. 2001, Maccari \& Morley-Fletcher 2007, Brunton \& Russell 2010). Antenatal glucocorticoid exposure also has similar 'programming effects' in other species including non-human primates (de Vries et al. 2007).

Programming of altered offspring HPA axis activity (and hence circulating glucocorticoid levels) and/or peripheral glucocorticoid metabolism may be a key mechanism underpinning programming effects on both the brain and metabolism (Friedman et al. 1993, Huang et al. 2002). Prenatal dexamethasone administration in the last week of pregnancy is associated with increased expression of the glucocorticoid receptor (GR) in both liver and adipose tissue (Nyirenda et al. 1998, Cleasby et al . 2003) and with increased hepatic expression of genes known to be important in regulating gluconeogenesis, such as phosphoenolpyruvate carboxykinase (Pepck (Pck1); Nyirenda et al. 1998). These changes may be important in driving the observed alterations in glucose-insulin homoeostasis (Nyirenda et al. 1998). We have recently shown that, in rats, exposure to social stress in late pregnancy is associated with increased HPA axis responses to stress in both the male and female offspring (Brunton \& Russell 2010). This appears to be a result of increased drive of the stress axis by corticotrophin-releasing hormone neurones, concomitant with impaired central glucocorticoid feedback mechanisms (Brunton \& Russell 2010). However, it is not clear whether maternal stress during pregnancy results in changes in $G R$ expression in the periphery or alters the expression of other genes involved in glucocorticoid, carbohydrate or fatty acid metabolism.
A further level of control of glucocorticoid action occurs at a tissue level as a consequence of intracellular metabolism in target cells. Glucocorticoids are metabolised by the $11 \beta$ HSDs and the A-ring reductase enzymes $5 \alpha$ - and $5 \beta$-reductase. Of these enzymes, $11 \beta \mathrm{HSD} 1$, which reactivates glucocorticoids from their inert 11-keto metabolites, and the A-ring reductase enzymes which are involved in glucocorticoid clearance, are highly expressed in liver and may contribute to bulk glucocorticoid metabolism. Altered steroid clearance as a consequence of alterations in the expression and activity of these enzymes can impact on HPA axis activity and maintain circulating glucocorticoid levels (Kotelevtsev et al. 1997, Harris et al. 2001). Programming of altered peripheral glucocorticoid metabolism has been reported in models of prenatal glucocorticoid overexposure with documented changes in hepatic and renal 11ßHSD1 expression (Nyirenda et al. 2009, Tang et al. 2011). Additionally, reduced $5 \alpha$-reductase activity has been proposed as an important contributor to the 'programmed' phenotype seen in individuals exposed to the severe physical, nutritional and psychological challenges of the World War II Holocaust early in life who subsequently developed post-traumatic stress disorder (PTSD; Yehuda et al. 2009a).

In this study, we exposed pregnant rats to an ethologically relevant social stress paradigm (to more accurately model the type of stress pregnant women may experience) with the aim of establishing whether PNS leads to alterations in glucose tolerance, insulin resistance and the expression of genes known to be important in regulating glucose and lipid metabolism and glucocorticoid action in liver, adipose and muscle in the adult offspring.

\section{Materials and methods}

\section{Animals}

Sprague Dawley rats weighing 270-295 g were purchased from Charles River Laboratories (Margate, Kent, UK). Rats were housed in a SPF rodent facility in open top cages, initially in groups of four to six, with food (standard maintenance rat chow, $14 \%$ protein and $4 \%$ fat) and water available ad libitum, under standard conditions of temperature $\left(20-21^{\circ} \mathrm{C}\right)$, humidity $(50-60 \%)$ and lighting (12 h light: $12 \mathrm{~h}$ darkness cycle, lights on at $0700 \mathrm{~h}$ GMT). Pregnant rats were obtained by overnight mating with a sexually experienced male and pregnancy was confirmed by the presence of a semen plug in the breeding cage the following morning, designated day 1 of pregnancy (parturition expected on day 22). All pregnant rats had

Published by Bioscientifica Ltd. 
their standard chow supplemented with breeding diet (19\% protein and 9\% fat) throughout gestation and lactation. Pregnant rats were caged singly from day 14 . The numbers of rats in each group are given in the relevant figure legends. All procedures were performed with approval from the University of Edinburgh Ethical Committee and in accordance with the UK Home Office Animals (Scientific Procedures) Act, 1986 legislation.

\section{PNS model}

Pregnant rats were exposed to stress during late gestation at a time when the fetal neuroendocrine and endocrine systems are differentiated and functional. Pregnant 'intruder' rats were placed in the cage of an unfamiliar aggressive lactating 'resident' rat (days 2-8 of lactation; day 1, day of parturition) for $10 \mathrm{~min}$ between 0900 and $1200 \mathrm{~h}$ on five consecutive days starting on day 16 of gestation (Brunton \& Russell 2010). Intruder rats were paired with a different lactating resident for each social defeat exposure. Following the final defeat on day 20, pregnant rats remained undisturbed, except for routine husbandry, in their home cage through parturition and lactation. Pregnant control rats remained in their home cages throughout. All rats were weighed daily during the stress exposure period. Soon after parturition, litter size, pup weights and male:female ratio of each litter was recorded. Litter sizes were not adjusted and dams remained with their litters until weaning on postnatal day 22. After weaning, the offspring were housed in groups by litter and sex under standard conditions (described earlier). For each experiment, groups were selected across litters, i.e. one male and one female (selected at random stages of the oestrous cycle) from each litter were used to directly compare differences between control and PNS offspring. The number of rats per group was 10, unless otherwise stated in the relevant figure legend.

\section{Jugular vein cannulation, blood sampling and blood glucose measurements}

Rats were fitted with a silastic (bore, $0.5 \mathrm{~mm}$; wall, $0.25 \mathrm{~mm}$ ) jugular vein cannula filled with sterile heparinised $(50 \mathrm{U} / \mathrm{ml})$ saline $(0.9 \%)$ under halothane anaesthesia (2-3\% in $1200 \mathrm{ml} / \mathrm{min}$ oxygen). Following surgery, rats were caged singly. Three or four days later, between 0800 and $0900 \mathrm{~h}$, silastic cannulae were connected to PVC tubing filled with sterile heparinised saline and connected to a $1 \mathrm{ml}$ syringe. Rats were left undisturbed in their home cage for $90 \mathrm{~min}$ and then two basal blood samples (ca. $30 \mu \mathrm{l}$ ) were collected $30 \mathrm{~min}$ apart from male (aged 11-12 weeks) and female (aged 12-13 weeks) control and PNS offspring. Next, rats were restrained in a ventilated Perspex tube (internal diameter, $65 \mathrm{~mm}$; length adjusted for each rat) for $30 \mathrm{~min}$. Further blood samples were collected 15, 30 and $60 \mathrm{~min}$ after the onset of restraint. Non-stressed controls remained in their home cages throughout. Withdrawn blood was replaced with sterile saline $(0.9 \%)$. Blood glucose concentrations were determined immediately using Accu-chek Active test strips (Roche) and an Accu-check blood glucose meter (Roche). The principle of the test is based on the glucose oxidase/peroxidase reaction and the manufacturers have determined that it is specific for glucose. The detection range of the test strips used was $0.5-33.3 \mathrm{mmol} / 1$. Plasma corticosterone concentrations were also determined and are published elsewhere (Brunton \& Russell 2010).

\section{Glucose tolerance tests, plasma and tissue lipid parameters}

Oral glucose tolerance tests (OGTTs) were performed in rats at 3 months and again at 6 months of age as described previously (Drake et al. 2005). Briefly, rats were fasted overnight (from $1600 \mathrm{~h}$ ) before administration of $2 \mathrm{~g} / \mathrm{kg}$ glucose solution $(0.5 \mathrm{~g} / \mathrm{ml})$ by oral gavage the following morning (between 0830 and $0915 \mathrm{~h}$ ). Tail-nick blood samples were collected at 0,30 and $120 \mathrm{~min}$. Plasma was separated and stored at $-20^{\circ} \mathrm{C}$. Glucose was determined by the hexokinase method (Sigma) and plasma insulin by ELISA (Crystal Chem, Downers Grove, IL, USA). Plasma triglycerides were measured on the fasted sample, using Infinity Triglyceride Liquid Stable Reagent and plasma cholesterol was quantified using the Infinity Cholesterol Liquid Stable Reagent (both from Thermo Electron, Pittsburgh, PA, USA).

The day after the 6-month OGTT (ca. $27 \mathrm{~h}$ after OGTT), rats were killed by an overdose of carbon dioxide. Epididymal, mesenteric and retroperitoneal fat depots and the liver were rapidly removed and weighed before being frozen on dry ice. Samples of subcutaneous fat and skeletal muscle (quadriceps) were also removed and frozen on dry ice. Tissue was stored at $-80^{\circ} \mathrm{C}$ until subsequent assay. For analysis of tissue triglyceride contents, liver and quadriceps tissue $(\sim 100 \mathrm{mg})$ were digested at $55^{\circ} \mathrm{C}$ overnight in $10 \%(\mathrm{w} / \mathrm{v})$ potassium hydroxide in ethanol; undigested tissue was removed by centrifugation at $15000 \boldsymbol{g}$ for $5 \mathrm{~min}$. The supernatant was removed, mixed with $1 \mathrm{M}$ magnesium chloride (1:1), vortexed, incubated on ice for $10 \mathrm{~min}$ and centrifuged at $15000 \boldsymbol{g}$ for $5 \mathrm{~min}$. The supernatant was used to measure triglyceride using Infinity Triglyceride Liquid Stable Reagent (Thermo Electron).

Published by Bioscientifica Ltd. 
Table 1 Details of primers used for real time PCR assays

\begin{tabular}{|c|c|c|c|c|c|}
\hline Gene & Abbreviation & Forward primer & Reverse primer & UPL & ABI assay ID \\
\hline AMP-activated protein kinase 2 & Ampk2 & ccggaggtcatctcagga & agggcatacaggataacacca & 50 & \\
\hline Adiponectin & AdipoQ & tggtcacaatgggataccg & cccttaggaccaagaacacct & 80 & \\
\hline Adipose triglyceride lipase & Atgl & & & & Rn01479969_m1 \\
\hline Cyclophilin A & & & & & Rn00690933_m1 \\
\hline Diacylglycerol acyltransferase 1 & Dgat1 & ccgtggtatcctgaattggt & aaaaataaccttgcattactcagga & 9 & \\
\hline Diacylglycerol acyltransferase 2 & Dgat2 & gtgtggcgctattttcgag & ggtcagcaggttgtgtgtctt & 42 & \\
\hline Glucocorticoid receptor & & & & & Rn01405584_m1 \\
\hline $\begin{array}{l}\text { 11ß-Hydroxysteroid } \\
\text { dehydrogenase type } 1\end{array}$ & $11 \beta h s d 1$ & $\begin{array}{l}\text { tctacaaatgaagagttca- } \\
\text { gaccag }\end{array}$ & gccccagtgacaatcacttt & 1 & \\
\hline Leptin & & & & & Rn00565158_m1 \\
\hline Lipoprotein lipase & $L p l$ & & & & $\mathrm{Rn} 00561482 \_\mathrm{m} 1$ \\
\hline $\begin{array}{l}\text { Phosphoenolpyruvate } \\
\text { carboxykinase }\end{array}$ & Pepck & & & & Rn01529014_m1 \\
\hline $\begin{array}{l}\text { Peroxisome proliferator- } \\
\quad \text { activated receptor coactivator } 1 \alpha\end{array}$ & $\operatorname{Pgc1} \alpha$ & & & & Rn00580241_m1 \\
\hline $\begin{array}{l}\text { Peroxisome proliferator- } \\
\text { activated receptor } \alpha\end{array}$ & Ppar $\alpha$ & & & & Rn00566193_m1 \\
\hline $\begin{array}{l}\text { Peroxisome proliferator- } \\
\text { activated receptor } \gamma\end{array}$ & Ppary & & & & Rn00440945_m1 \\
\hline $5 \alpha$-Reductase & $5 \alpha R$ & ctgggcaacctccctaac & gggaaaaccagcgtgcct & 18 & \\
\hline $5 \beta$-Reductase & $5 \beta R$ & gagatgcccatggccttta & cactcggccattctcatctt & 80 & \\
\hline Uncoupling protein 2 & Ucp2 & $\begin{array}{l}\text { gactctgtaaagcagttcta- } \\
\text { caccaa }\end{array}$ & gggcacctgtggtgctac & 79 & \\
\hline
\end{tabular}

UPL, Universal Probe Library

\section{Corticosterone RIA}

Plasma corticosterone concentrations were determined using a commercially available RIA kit (MP Biomedical, Cambridge, UK). The sensitivity of the assay was $25 \mathrm{ng} / \mathrm{ml}$ and intra-assay variation was $4-5 \%$. All samples were measured in a single RIA.

\section{Quantification of mRNA by real-time PCR}

Total RNA was extracted from snap-frozen liver, adipose and quadriceps muscle using the Qiagen RNeasy system (Qiagen Ltd.) and reverse transcribed using the Promega RT kit (Promega UK Ltd.). cDNA (equivalent to $1 \mathrm{ng}$ total RNA) was incubated in triplicate with gene-specific primers and fluorescent probes (either using the UPL system from Roche Diagnostics Ltd., or predesigned assays from Applied Biosystems) in $1 \times$ Roche LightCycler 480 Probes mastermix (Table 1). PCR cycling and detection of fluorescent signal were carried out using a Roche LightCycler 480. A standard curve was constructed for each primer-probe set using a serial dilution of cDNA pooled from all samples. Results were corrected for the expression of cyclophilin A, which was unchanged among groups. In this study, we set out to characterise the expression of genes important in glucocorticoid signalling and metabolism whose expression is altered in other models of programming and in humans (GR, 11ßHSD1 and $5 \alpha$ - and $5 \beta$-reductase). We also studied the expression of genes that we have previously shown to be altered as a consequence of prenatal dexamethasone overexposure (Nyirenda et al. 1998, 2009, Drake et al. 2010) and are known to be important in glucose-insulin homoeostasis and in lipid metabolism in liver, subcutaneous fat and muscle including Pepck, peroxisome proliferator-activated receptor $\alpha$ and $\gamma$ (Ppara (Ppara) and Ppary (Pparg)), peroxisome proliferator-activated receptor gamma coactivator $1 \alpha$ $(P g c 1 \alpha(P p a r g c 1 a))$, adipose triglyceride lipase (Atgl), diglyceride acyltransferase 1 and 2 (Dgat1 and 2), leptin, adiponectin (AdipoQ), AMP-activated protein kinase (Ampk (PRKAA1)) and uncoupling protein 2 (Ucp2).

Table 2 Body weight in control and PNS offspring. Body weight data are expressed in grams \pm S.E.M.

\begin{tabular}{|c|c|c|c|c|}
\hline $\begin{array}{l}\text { Postnatal } \\
\text { days }\end{array}$ & Control $\delta^{\pi}$ & PNS $0^{\pi}$ & Control 9 & PNS + \\
\hline 1 & $6.4 \pm 0.2$ & $6.0 \pm 0.2$ & $6.1 \pm 0.2$ & $5.6 \pm 0.1^{\dagger}$ \\
\hline 10 & $18.0 \pm 0.7$ & $17.2 \pm 0.8$ & $17.2 \pm 0.8$ & $16.5 \pm 0.6$ \\
\hline 22 & $44.5 \pm 1.6$ & $39.8 \pm 0.9$ & $41.1 \pm 1.5$ & $38.9 \pm 1.4$ \\
\hline 70 & $315.8 \pm 6.7$ & $295.9 \pm 8.3 *$ & $219.7 \pm 2.9$ & $214.2 \pm 6.0$ \\
\hline 91 & $400.1+7.0$ & $359.8+10.9^{\dagger}$ & $255.6+4.3$ & $241+7.0$ * \\
\hline 189 & $518.7 \pm 7.9$ & $478.1 \pm 16.0$ * & $303.4 \pm 6.0$ & $290 \pm 7.9$ \\
\hline
\end{tabular}

${ }^{*} P<0.05$ and ${ }^{\dagger} P<0.005$ vs control. Student's $t$-test, $n=16-17$ litters/ group for postnatal days $1-22$ and $n=10$ rats/group post-weaning. PNS, prenatal stress. $\begin{array}{lr}\text { http://joe.endocrinology-journals.org } & \text { (2013 Society for Endocrinology } \\ \text { DOI: } 10.1530 / \text { JOE-12-0540 } & \text { Printed in Great Britain }\end{array}$ 
Table 3 Tissue weights at 6 months of age. Data are expressed as percentage (\%) body weight \pm s.E.M.

\section{Organ/fat \\ depot}

Liver

Retroperitoneal

fat

Mesenteric fat

Epididymal fat

\begin{tabular}{|c|c|}
\hline Control ot & PNS \\
\hline $3.44 \pm 0.07$ & $3.98 \pm 0.10$ * \\
\hline $0.70 \pm 0.01$ & $0.60 \pm 0.06$ \\
\hline $0.62 \pm 0.06$ & $0.57 \pm 0.04$ \\
\hline $0.64 \pm 0.06$ & $0.61 \pm 0.04$ \\
\hline
\end{tabular}

\begin{tabular}{|c|c|}
\hline Control 9 & PNS 우 \\
\hline $\begin{array}{l}3.56 \pm 0.10 \\
0.61 \pm 0.06\end{array}$ & $\begin{array}{l}3.65 \pm 0.10 \\
0.53 \pm 0.07\end{array}$ \\
\hline $\begin{array}{c}0.75 \pm 0.05 \\
-\end{array}$ & $\begin{array}{c}0.66 \pm 0.08 \\
-\end{array}$ \\
\hline
\end{tabular}

\section{Statistical analysis}

Blood glucose in response to restraint and plasma glucose, insulin and corticosterone data from the OGTT studies were analysed using either a one-way or a two-way repeated measures (RM) ANOVA or Friedman RM ANOVA on ranks (Sigmaplot v11.0, Systat Software, Inc., Chicago, IL, USA). Enzyme mRNA expression in liver, adipose and muscle was analysed using Student's $t$-test. Plasma triglycerides, cholesterol, body weight and organ weights were also analysed by Student's t-test. In each case, the analyses conducted were stratified by sex, and $P<0.05$ was considered statistically significant. Data are presented as mean \pm s.E.M.

\section{Results}

\section{Litter size, body weight and organ weight}

Social stress did not affect maternal weight gain. The increase in body weight between gestation days 16-20 was $42.0 \pm 3.0 \mathrm{~g}$ in controls (11.7\% increase) and $44.6 \pm 2.1 \mathrm{~g}$ in the social stress group (12.6\% increase).

PNS had no significant effect on litter size (controls: $13.0 \pm 0.6$, mode $=13$; PNS: $13.4 \pm 1.3$, mode $=14 ; n=17$ and 161 respectively) or the proportion of male:female pups in the litters (1:1.1 and 1:0.9 in the control and PNS litters respectively). Birth weight was not significantly different between PNS and control males (Table 2). However, the female PNS offspring had significantly lower birth weights (Table 2), including when litter size was controlled for $\left(F_{(1,31)}=18.7, P<0.001\right.$; ANCOVA). Catch up growth occurred postnatally such that there were no significant differences in weight between control and PNS females on postnatal day 10, at weaning on postnatal day 22 or at 10 weeks of age (Table 2). PNS females weighed less than control females at 3 months, but body weight had normalised by 6 months of age
(Table 2). However, despite there being no difference in body weight between control and PNS males in the first 3 weeks of life while suckling (Table 2), PNS males weighed significantly less than controls at 10 weeks, 3 months and 6 months of age (Table 2).

There were no differences in the weight of mesenteric, retroperitoneal or epididymal fat depots corrected for body weight; however, PNS males had heavier livers (Table 3; $P<0.001)$. There were no differences between PNS and control females in liver weight or fat depot weights (Table 3 ) at 6 months of age.

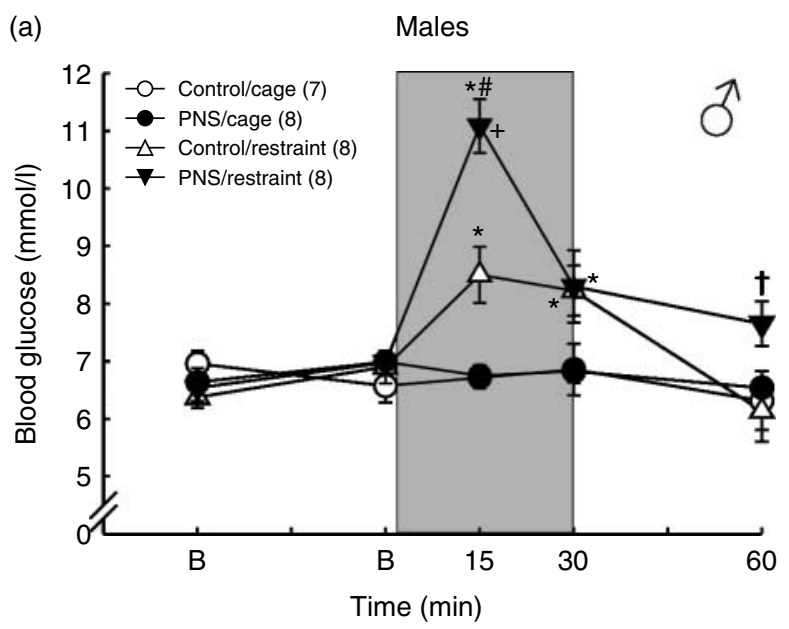

(b)

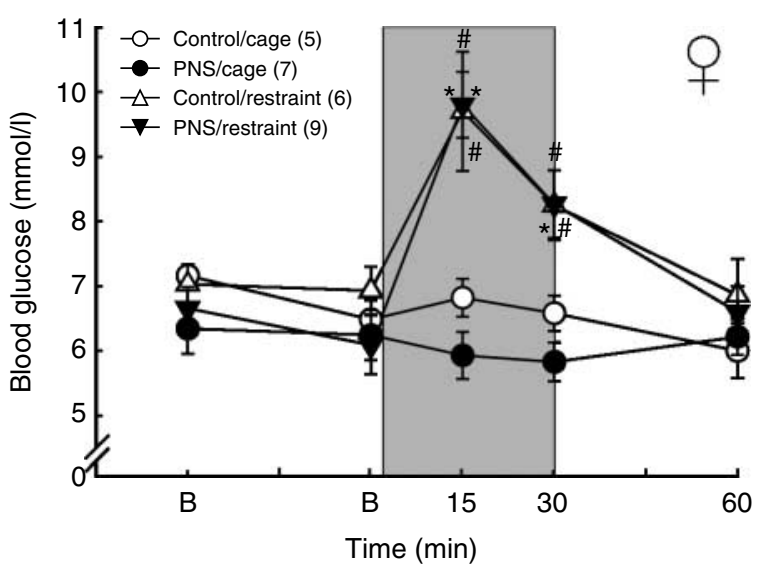

Figure 1

Blood glucose responses to acute restraint. Basal (B) blood samples were collected from conscious male ( $\left.\delta^{(}\right)$and female ( $(\$)$ control and prenatally stressed (PNS) rats before and after 30-min restraint (shaded bar) or not (cage). Blood glucose concentrations in (a) male and (b) female rats. Statistics: ${ }^{*} P<0.01$ vs $B$ within same group; ${ }^{+} P<0.001$ vs control/restraint group at same time point; ${ }^{\#} P<0.001$ vs cage groups at same time point; two-way RM ANOVA. Data are group means \pm s.E.M. Rat numbers per group are in parenthesis in the figure key. 

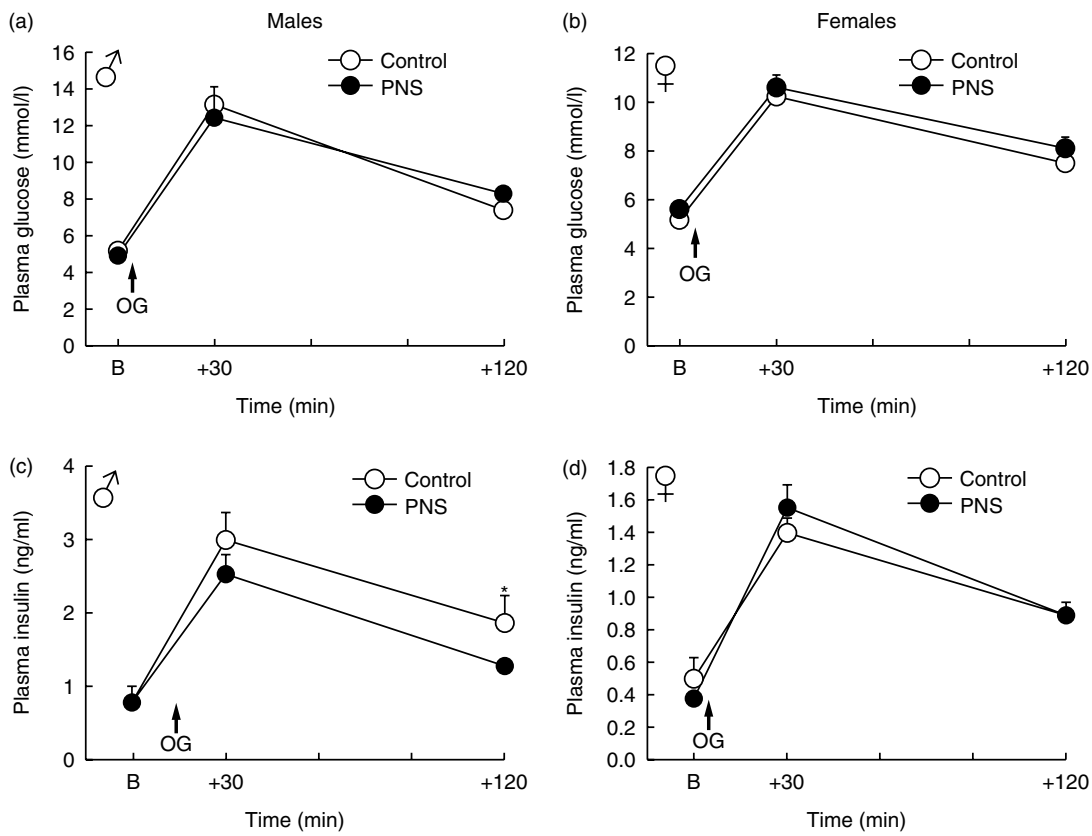

\section{Figure 2}

Oral glucose tolerance testing at 3 months. One basal (B) blood sample was collected from conscious 3-month-old male ( $\delta^{(0)}$ and female ( $(\$)$ control and prenatally stressed (PNS) rats. Immediately after the basal sample, all rats were administered $2 \mathrm{~g} / \mathrm{kg}$ glucose solution (0.5 g/ml) by oral gavage (OG). Further blood samples were collected 30 and $120 \mathrm{~min}$ after the glucose load. Plasma glucose concentrations in (a) male and (b) female rats and plasma insulin concentrations in (c) male and (d) female rats. Statistics: ${ }^{*} P<0.05$ vs PNS group at same time point; Friedman RM ANOVA on ranks. Data are group means + S.E.M. Rat numbers $=10 /$ group.

\section{Metabolism}

Blood glucose responses to acute restraint stress Males At 3 months of age, basal blood glucose concentrations were not different between control and PNS males (Fig. 1a). Restraint stress significantly increased blood glucose concentrations $\left(F_{(3,106)}=15.3\right.$; two-way RM ANOVA; Fig. 1a) in both control and PNS males; however, the response was significantly greater in the PNS males (1.3-fold greater response at $15 \mathrm{~min}$, $P<0.001$; Fig. 1a).

Females Basal blood glucose concentrations were not different between 3-month-old control and PNS females (Fig. 1b). Restraint stress significantly increased blood glucose concentrations $\left(F_{(3,92)}=10.7\right.$; two-way RM ANOVA, $P<0.001$; Fig. 1b) with no differences between the groups.

Glucose tolerance testing: 3 months At 3 months of age, there were no differences in basal plasma glucose concentrations between male (Fig. 2a) and female (Fig. 2b) control and PNS rats and no differences in the response to an oral glucose load between control and PNS rats in either sex (Fig. 2a and b). There was no difference in basal or peak plasma insulin concentrations between control and PNS male (Fig. 2c) or female rats (Fig. 2d); insulin concentration at $2 \mathrm{~h}$ was lower in PNS males than in controls (Fig. 2c; $P<0.05$, Friedman RM ANOVA on ranks). Females had significantly lower insulin concentrations than males under basal conditions $\left(F_{(1,36)}=7.0\right.$, $P=0.012$; two-way ANOVA) and $30 \mathrm{~min}\left(F_{(1,36)}=28.8\right.$, $P<0.001)$ after glucose administration, regardless of prenatal treatment.

Glucose tolerance testing: 6 months At 6 months of age, there were no differences in plasma glucose or insulin concentrations before or after an OGTT between control and PNS males (Fig. 3a and c). Plasma glucose concentrations were not different between PNS and control females (Fig. 3b), but plasma insulin concentrations were significantly greater in the PNS females than in the control females ( $P=0.003$, one-way RM ANOVA) 30 min following oral glucose loading (Fig. 3d).

Corticosterone There was no difference in plasma corticosterone concentrations between male control and PNS rats (Fig. 3e) and female control and PNS rats (Fig. 3f) under basal conditions. The OGTT significantly increased circulating corticosterone in both the control $(P<0.001)$ and PNS $(P<0.001)$ males (Fig. 3e) and in the control

Published by Bioscientifica Ltd. 
(a)
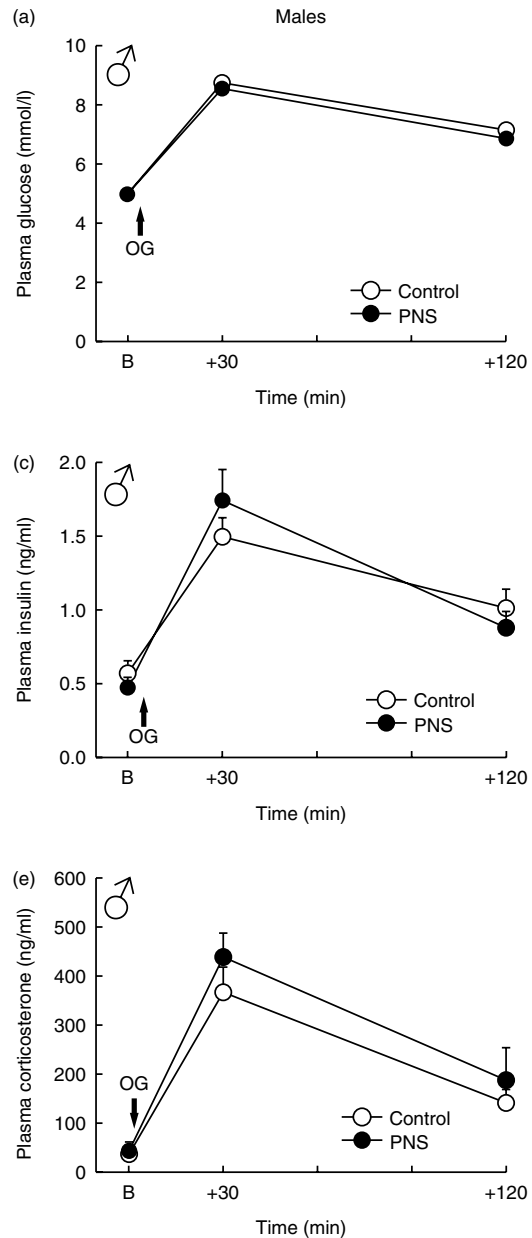

Figure 3

Oral glucose tolerance testing at 6 months. One basal (B) blood sample was collected from conscious 6-month-old male ( 6 ) and female (\$) control and prenatally stressed (PNS) rats. Immediately after the basal sample, all rats were administered $2 \mathrm{~g} / \mathrm{kg}$ glucose solution $(0.5 \mathrm{~g} / \mathrm{ml})$ by oral gavage (OG). Further blood samples were collected 30 and $120 \mathrm{~min}$ after the glucose

$(P<0.001)$ and PNS $(P<0.001)$ females (Fig. 3f $)$, with no significant effects of prenatal treatment. However, at each time point, plasma corticosterone concentrations were significantly greater in females than in males regardless of prenatal experience $\left(F_{(1,36)}=25.9, P<0.001\right.$; two-way ANOVA).

Lipids Plasma cholesterol concentrations were not different between control and PNS rats in either the males or females (Fig. 4a). PNS males had significantly greater circulating fasting concentrations of triglycerides than control males (Fig. $4 \mathrm{~b} ;{ }^{*} P<0.05$, Student's $t$-test); however, there were no differences in females (Fig. 4b). There were no differences between any of the groups in hepatic (Fig. 4c) or muscle triglyceride (Fig. 4d) contents. Printed in Great Britain
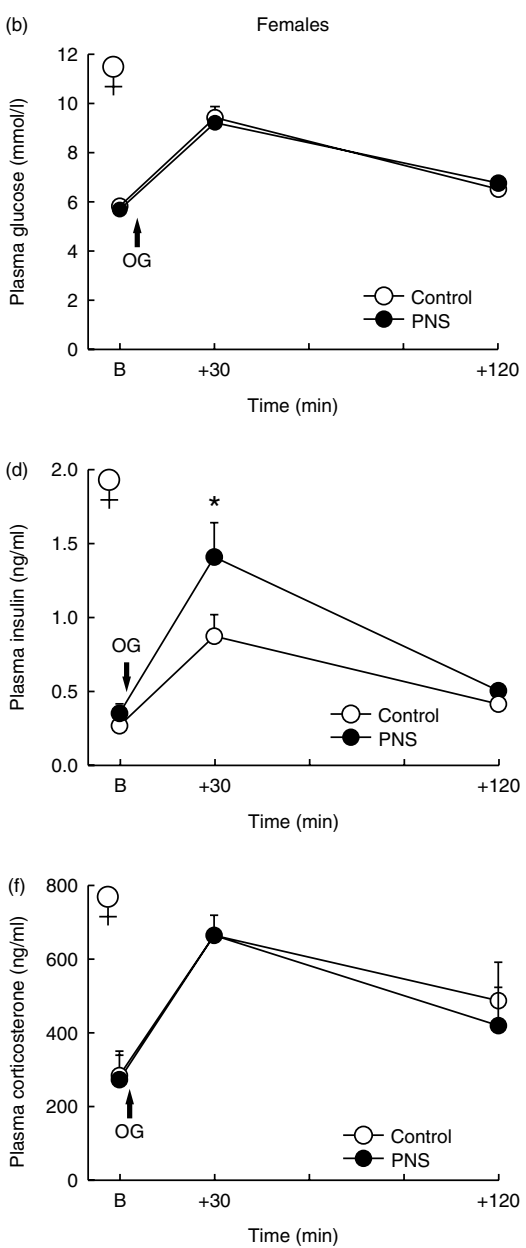

load. Plasma glucose concentrations in (a) male and (b) female rats; plasma insulin concentrations in (c) male and (d) female rats; and plasma corticosterone concentrations in (e) male and ( $f$ ) female rats. Statistics: $* P=0.003$ vs control group at same time point; one-way RM ANOVA. Data are group means + S.E.M. Rat numbers $=10 /$ group.

Peripheral gene expression Males PNS was associated with altered expression of genes important in glucocorticoid and lipid metabolism in liver and quadriceps muscle in the male rats. PNS reduced hepatic expression of mRNAs Ppara $(P=0.02$; Fig. 5a) and $5 \alpha$-reductase $(P=0.03$, Student's $t$-test; Fig. $5 a)$ and was associated with a trend towards a reduction in both Ppary $(P=0.058$; Fig. 5a) and $\operatorname{Pgc1} \alpha(P=0.056)$ mRNA levels. In subcutaneous fat, there was a significant reduction in Pepck mRNA level in the PNS males $(P=0.04$; Fig. 6a) and a trend towards a reduction in $G r$ mRNA level $(P=0.056$; Fig. 6a), with no changes in the expression of any of the other genes measured (Fig. 6a). In quadriceps, PNS significantly reduced $G r$ mRNA level $(P=0.04)$, and there was a trend to reduced Ppar $\alpha$ mRNA expression ( $P=0.06$; Fig. 7a).

Published by Bioscientifica Ltd. 

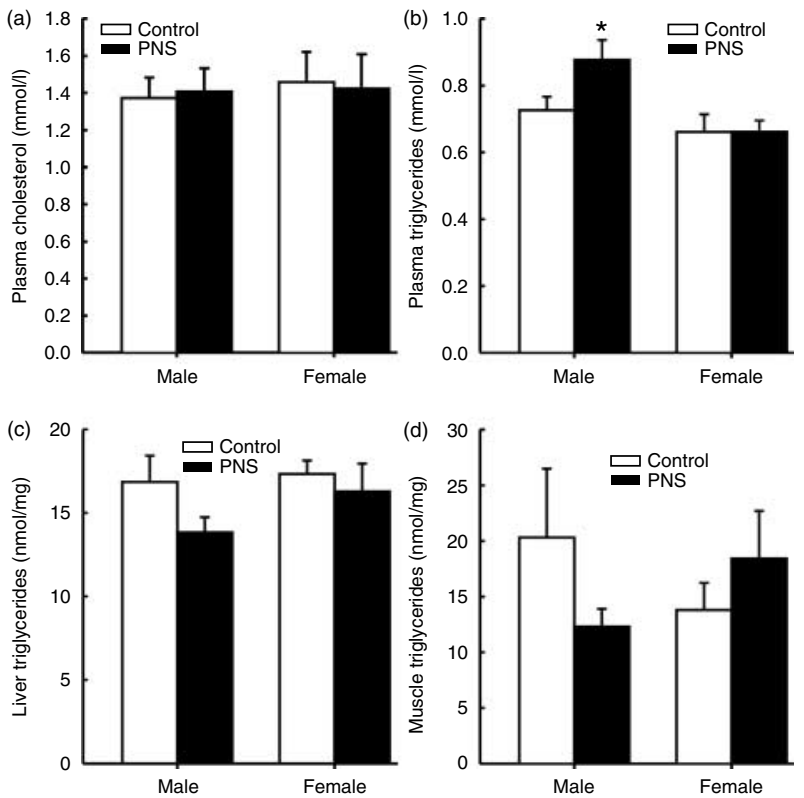

Figure 4

Plasma cholesterol and plasma, liver and muscle triglyceride concentrations. (a) There were no differences in plasma cholesterol levels between control and prenatal stress (PNS) males or females. (b) PNS was associated with increased plasma triglyceride concentrations in adult male but not female offspring. There were no differences in (c) liver or (d) muscle triglyceride concentrations in males or females. Statistics: ${ }^{*} P<0.05$ vs control group, Student's $t$-test. Data are group means + S.E.M. Rat numbers $=10 /$ group.

Females There were fewer changes in gene expression in liver and muscle in females; PNS significantly reduced mRNA levels for $P g c 1 \alpha$ in liver $(P=0.009$; Fig. $5 b)$ and Ppar $\alpha$ in quadriceps muscle $(P=0.03$; Fig. $7 \mathrm{~b})$. However, there were marked alterations in gene expression in subcutaneous fat in females (Fig. 6b), in which PNS reduced mRNA levels for Atgl, Dgat2, 11ßhsd1, leptin and Pepck, (Fig. 6b). PNS did not affect the expression of genes in mesenteric fat in either males (Fig. 6c) or females (Fig. 6d).

\section{Discussion}

Here, we have shown that PNS exposure results in sexspecific effects on glucose-insulin and lipid homoeostasis in the adult offspring. Male, but not female, PNS offspring exhibited markedly increased glucose responses to acute restraint, whereas PNS females, but not males, were hyperinsulinaemic following oral glucose load. Moreover, the expression of genes important in glucocorticoid and lipid metabolism was altered by PNS predominantly in liver and skeletal muscle in the male rats, whereas in females the majority of changes were observed in subcutaneous fat. Importantly, these changes occurred in the absence of obesity, consistent with our previous reports in a rat model of prenatal programming by dexamethasone (Drake et al. 2010). In these studies, while prenatal dexamethasone exposure did not alter the severity of obesity or the accumulation of adipose tissue induced by high-fat feeding, there was evidence of altered fatty acid metabolism in liver and adipose tissue with altered expression of a number of relevant genes (Drake et al. 2010). Taken together, these studies suggest that prenatal glucocorticoid overexposure is associated with primary alterations in gene expression, which increase the risk of metabolic dysfunction in the absence of an increased risk of obesity.

Maternal stress in late pregnancy caused a marked stress-induced increase in blood glucose in male offspring, indicative of disrupted glucose homoeostasis. Here, pups remained with their mothers until weaning. Maternal behaviour was not monitored in this study; however, our unpublished observations indicate that this PNS paradigm does not affect subsequent maternal behaviour and others have reported similar findings using social stress exposure combined with restraint during pregnancy (Neumann et al. 2005). Nonetheless, we cannot exclude altered maternal behaviour as a contributing factor in the programming effects that we observed. As we have previously shown that both male and female PNS offspring display greater corticosterone responses to stress (Brunton $\&$ Russell 2010) and that male rats exposed to dexamethasone during the last week of gestation have increased glucose levels in response to exogenous corticosterone (Nyirenda et al. 1998), the stress-induced increase in plasma glucose concentrations indicates that PNS may programme increased sensitivity to glucocorticoids in males. The mechanism(s) are not known but may involve glucocorticoid-mediated increases in hepatic gluconeogenesis and/or reduced glucose uptake by muscle and fat (Pilkis \& Granner 1992, Nyirenda et al. 1998, Cleasby et al. 2003), though this requires further investigation. Insulin homoeostasis was broadly unaltered in males; however, there was post-glucose hyperinsulinaemia in females indicating programming of increased insulin resistance and indicating gender-distinct mechanisms. Thus, PNS is associated with the programming of stress-induced hyperglycaemia in males and with hyperinsulinaemia in response to glucose in females.

The effects of PNS on hepatic gene expression were more marked in males than in females. In males, PNS decreased hepatic mRNA encoding Ppard, a key regulator of systemic and intrahepatic lipid homoeostasis (Leone 


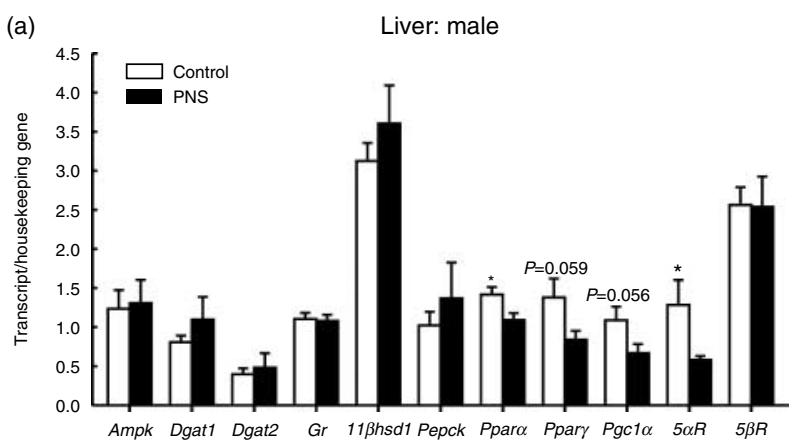

(b)

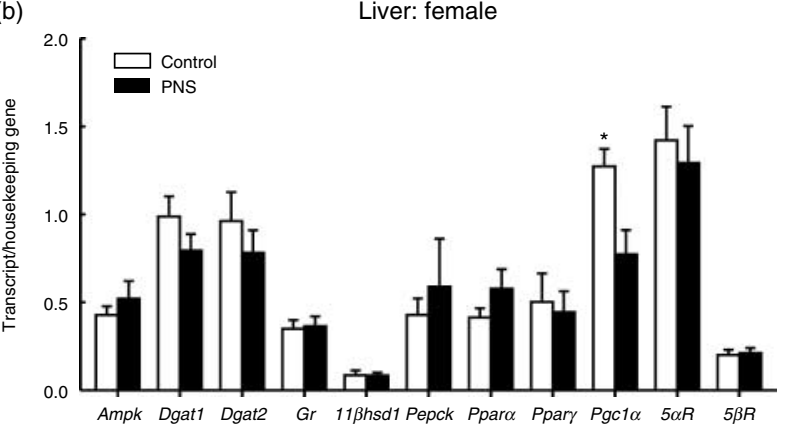

Figure 5

Hepatic gene expression at 6 months. (a) Prenatal stress (PNS) was associated with reduced expression of mRNAs for $5 \alpha$-reductase $(5 \alpha R)$ and peroxisome proliferator-activated receptor $\alpha$ (Ppar $\alpha$ ) in males. (b) In females, PNS was associated with reduced expression of peroxisome proliferator-activated receptor $\gamma$ coactivator $1 \alpha(P g c 1 \alpha)$ mRNA. Statistics: ${ }^{*} P<0.04$ vs control group; Student's $t$-test. Data are normalised to the expression of the housekeeping gene cyclophilin A. Data are group means+S.E.M. Rat numbers=10/group. Ampk, AMP-activated protein kinase; Dgat, diglyceride acyltransferase; Gr, glucocorticoid receptor; $11 \beta h s d 1,11 \beta$-hydroxysteroid dehydrogenase type 1; Pepck, phosphoenolpyruvate carboxykinase; Ppar $\gamma$, peroxisome proliferator-activated receptor $\gamma ; 5 \beta R, 5 \beta$-reductase.

et al. 1999, Akiyama et al. 2001). Consistent with this, plasma triglyceride concentrations were increased in PNS males, and although hepatic triglyceride levels were not altered by PNS in rats here fed a normal diet, we have previously shown that exposure to a high-fat diet drives the development of hepatic steatosis in male rats exposed to dexamethasone prenatally (Drake et al. 2010). Reduced hepatic PPAR $\gamma$ occurs in offspring of dams exposed to dexamethasone (Drake et al. 2010) or dietary restriction (Magee et al. 2008); here, the trend for reduced Ppary mRNA expression in PNS males indicates that PPAR $\gamma$ may be particularly sensitive to the prenatal environment. Hepatic Pgc1 $1 \alpha$ mRNA expression was significantly decreased in PNS females, with a similar trend in males, consistent with the effects of prenatal dexamethasone exposure (Drake et al. 2010). Pgc1 $\alpha$ has a key role in the regulation of multiple pathways involved in the control of energy metabolism; in animal models, hepatic $P g c 1 \alpha$ deficiency causes the development of hepatic steatosis (Leone et al. 2005, Estall et al. 2009), and in humans, $P G C 1 \alpha$ expression is reduced in patients with nonalcoholic fatty liver disease (Westerbacka et al. 2007). Thus, these changes in the expression of key genes in fatty acid metabolism in liver indicate that programming of increased susceptibility to hepatic fat accumulation appears to be a common outcome of PNS/glucocorticoid overexposure.

Intriguingly, Ppar $\alpha$ expression was also reduced in skeletal muscle in PNS females with a similar trend in PNS males. In addition to its role in hepatic lipid metabolism, PPAR $\alpha$ may play a key role in muscle lipid metabolism (Muoio et al. 2002, Boyle et al. 2011) and reduced muscle lipid oxidation may precede lipid accumulation and insulin resistance (Kim et al. 2000, Muoio et al. 2002). Importantly, ageing exacerbates the phenotypic abnormalities associated with Ppara deficiency (Atherton et al. 2009), which might also exacerbate the phenotype associated with PNS.

The finding of down-regulated hepatic $5 \alpha$-reductase mRNA in male PNS rats is complemented by findings from human studies. Elderly survivors of the World War II Holocaust display threefold lower $5 \alpha$-reduction of cortisol, indicative of reduced hepatic $5 \alpha$-reductase type 1 activity (Yehuda et al. 2009a). The greatest reductions in $5 \alpha$-reductase activity were observed in those individuals who were the youngest at exposure to the Holocaust, indicating a potential 'programming' window in early life. Remarkably, in 9/11-exposed individuals with PTSD, lower $5 \alpha$-reductase activity predicts resistance to psychotherapy (Yehuda et al. 2009b). While the mechanisms accounting for reduced $5 \alpha$-reductase expression are unclear, $5 \alpha$-reductase expression is 'programmed' in early life by androgens (Gustafsson \& Stenberg 1974), and additionally, in adulthood, testosterone deficiency increases, while testosterone administration reduces hepatic $5 \alpha$-reductase activity (Gustafsson \& Stenberg 1974). Circulating testosterone levels are markedly elevated in PNS males (PJ Brunton \& JA Russell, unpublished observations), so increased testosterone may contribute to the reduced hepatic $5 \alpha$-reductase expression. The physiological significance of down-regulated hepatic $5 \alpha$-reductase in PNS offspring is not fully understood. It may be an adaptive response to PNS exposure, where a shift in metabolism acts to prolong local glucocorticoid action in the liver (by down-regulating corticosterone inactivation in the liver by $5 \alpha$-reductase), advantageous in generating fuels to meet metabolic demand. In accordance

Published by Bioscientifica Ltd. 
with the reduction in hepatic $5 \alpha$-reductase expression in PNS male rats, $5 \alpha$-reductase mRNA expression in the brains of fetal, prepubertal and adult PNS rats is downregulated (Ordyan \& Pivina 2005, Paris et al. 2011, PJ Brunton \& JA Russell, unpublished observations). In the brain, $5 \alpha$-reductase generates neurosteroids such
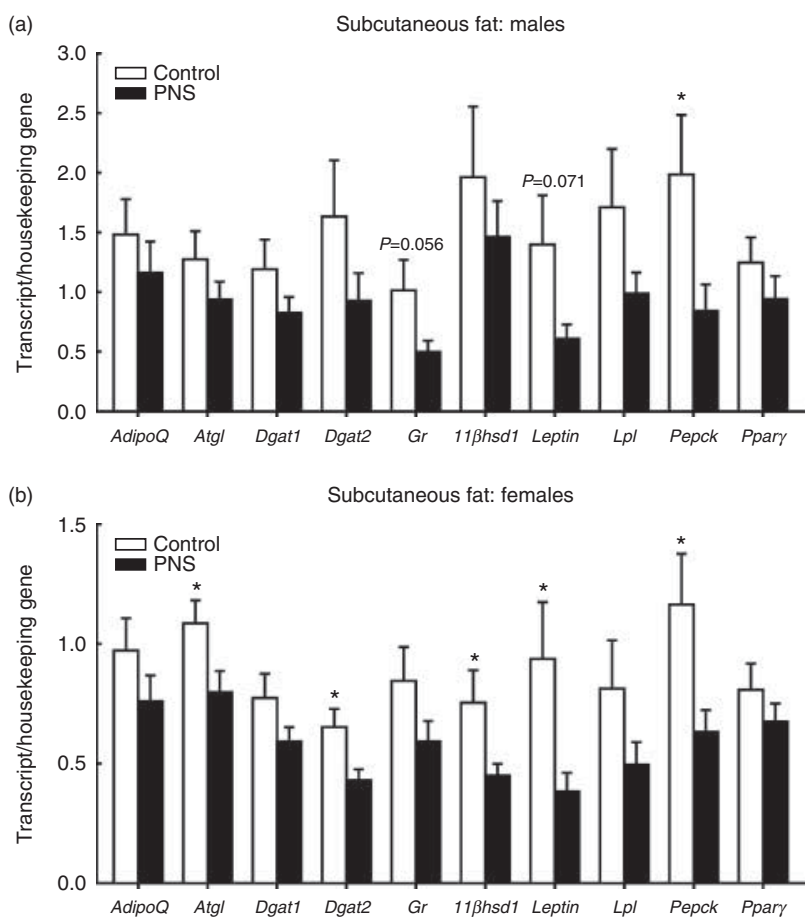

(c)
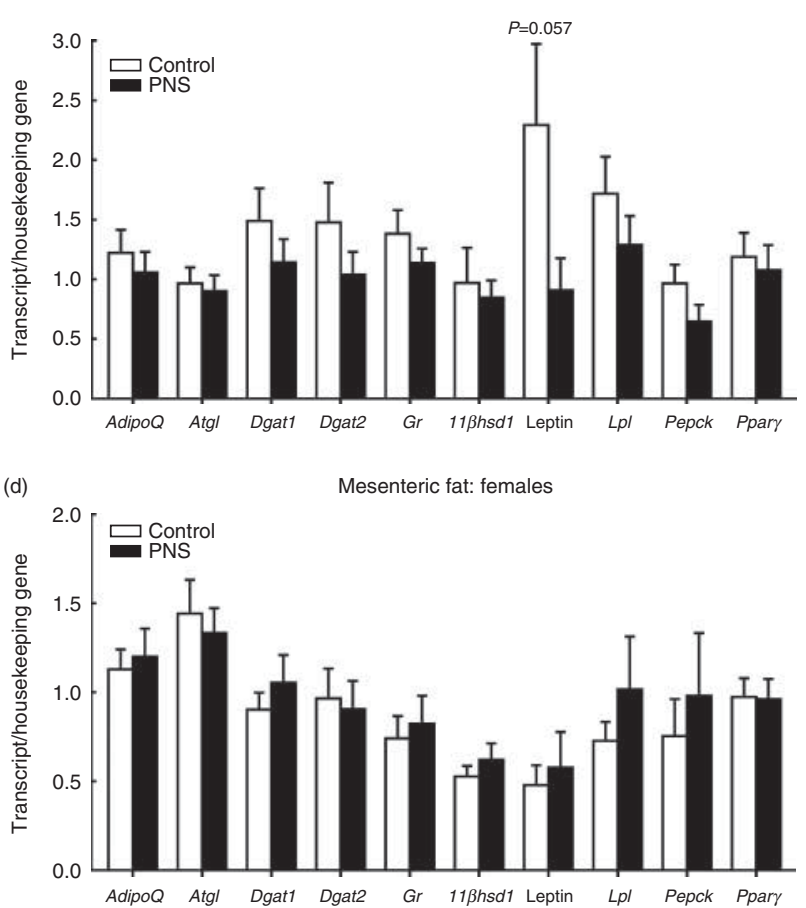

http://joe.endocrinology-journals.org DOI: $10.1530 / J O E-12-0540$

C 2013 Society for Endocrinology Printed in Great Britain as allopregnanolone ( $3 \alpha$-hydroxy-5 $\alpha$-pregnan-20-one) and

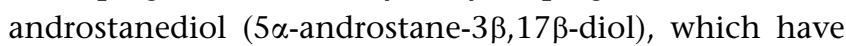
anxiolytic and stress-reducing actions (Bitran et al. 1995, Patchev et al. 1996, Edinger \& Frye 2004, Brunton et al. 2009, Handa et al. 2009). Hence, reduced central $5 \alpha$ reductase expression is consistent with the anxious and stress hyper-reactive phenotype of PNS rats (Brunton \& Russell 2010). Evidently, equivalent changes in $5 \alpha$ reductase expression in liver and in brain in response to PNS may be adaptive to promote metabolic efficiency and a cautious behavioural strategy. Additionally, consistent with changes predicting altered glucocorticoid metabolism in target tissues and in agreement with our previous studies in males exposed to dexamethasone prenatally (Cleasby et al. 2003), GR mRNA expression was reduced in skeletal muscle of PNS males.

In contrast to the findings in liver, alterations in the expression of genes in subcutaneous adipose tissue were more pronounced in PNS females. Decreased expression of 11ßhsd1 mRNA in PNS females would predict decreased local corticosterone regeneration and lower tissue glucocorticoid levels, while decreased expression of Atgl and Dgat2 mRNAs in PNS females indicates decreased lipid turnover. ATGL is regulated by glucocorticoids (Serr et al. 2011) and insulin (Yao-Borengasser et al. 2011), so altered Atgl mRNA expression may be a consequence of decreased tissue glucocorticoid concentrations and/or higher insulin levels. In adipose tissue, PEPCK is a key enzyme in glyceroneogenesis where it increases the incorporation of free fatty acids into triglycerides; thus, the reduction in subcutaneous fat Pepck mRNA expression may predict increased free fatty acid release into the circulation (Hanson \& Reshef 2003, Olswang et al. 2003) and promote insulin resistance (Paolisso et al. 1995, Boden \& Shulman 2002). It is not clear what triggers reduced Pepck gene expression; however, adipose Pepck expression is downregulated by insulin and glucocorticoids (Granner et al. 1983, Nechushtan et al. 1987). Leptin mRNA expression

\section{Figure 6}

Gene expression in subcutaneous and mesenteric fat depots at 6 months. Prenatal stress (PNS) was associated with a significant reduction in subcutaneous fat in level of (a) Pepck mRNA in males and (b) 11ß-hydroxysteroid dehydrogenase type 1 (11ßhsd1), phosphoenolpyruvate carboxykinase (Pepck), adipose triglyceride lipase (Atgl) and diglyceride acyltransferase 2 (Dgat2) mRNAs in females. There were no changes in gene expression in mesenteric fat in either (c) males or (d) females. Statistics: ${ }^{*} P<0.05$ vs control group, Student's $t$-test. Data are normalised to the expression of the housekeeping gene cyclophilin A. Data are group means+s.E.M. Rat numbers $=10 /$ group. AdipoQ, adiponectin; Atgl, adipose triglyceride lipase; Gr, glucocorticoid receptor; $L p l$, lipoprotein lipase; Ppar $\gamma$, peroxisome proliferator-activated receptor $\gamma$.

Published by Bioscientifica Ltd. 
(a)
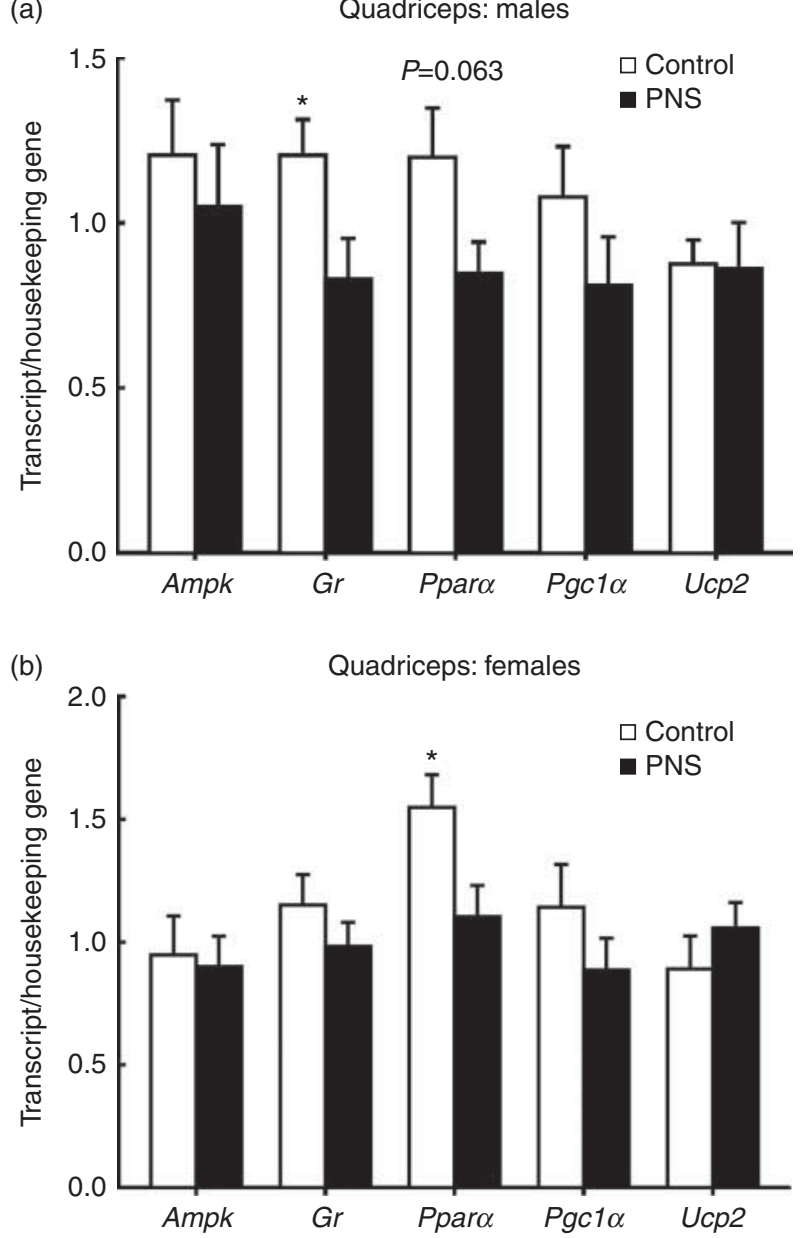

Figure 7

Gene expression in quadriceps muscle at 6 months. (a) Prenatal stress (PNS) was associated with reduced level of glucocorticoid receptor (Gr) mRNA in males. (b) PNS was associated with reduced level of Ppar $\alpha$ mRNA in females. Statistics: ${ }^{*} P<0.04$ vs control group, Student's $t$-test. Data are normalised to the mRNA level of the housekeeping gene cyclophilin A. Data are group means+s.E.M. Rat numbers $=10 /$ group. Ampk, AMP-activated protein kinase; Pgc1 $\alpha$, peroxisome proliferator-activated receptor $\gamma$ coactivator $1 \alpha$; Ucp2, uncoupling protein 2.

was also reduced in subcutaneous fat in PNS females with a similar trend in mesenteric and subcutaneous fat of PNS males. Reduced leptin expression may lead to reduced leptin signalling to the central appetite and metabolism regulating neurones; indeed, developmental programming of leptin signalling is considered to be of importance in the development of the associated metabolic phenotype (Cottrell \& Ozanne 2007).

In summary, PNS exposure resulted in effects on glucose-insulin and lipid homoeostasis and on peripheral gene expression in liver, adipose and skeletal muscle in the adult offspring, with particular effects on the expression of genes known to regulate lipid and glucocorticoid metabolism. Importantly, these changes are sex specific. The mechanisms that account for sexspecific programming effects are unclear but may include the effects of sex chromosomes or pre- and/or postnatal changes in sex steroid levels (Gabory et al. 2009), and our work further highlights the need for research aimed at understanding early life programming mechanisms in both sexes (Koletzko et al. 2011). Additionally, whether a more dramatic 'disease' phenotype would be observed in both male and female PNS offspring with ageing, poor postnatal diet or chronic stress exposure warrants further investigation.

\section{Declaration of interest}

The authors declare that there is no conflict of interest that could be perceived as prejudicing the impartiality of the research reported.

\section{Funding}

This work was supported by the Biotechnology and Biological Sciences Research Council (grant number: BB/C518957/1) to J A R/P J B and the Medical Research Council (grant number: G0501904) to A J D.

\section{Acknowledgements}

The authors thank Helen Cameron for technical assistance. Undergraduate students Megan Carr and Stella Howgate assisted in some of the experiments reported here.

\section{References}

Akiyama TE, Nicol CJ, Fievet C, Staels B, Ward JM, Auwerx J, Lee SS, Gonzalez FJ \& Peters JM 2001 Peroxisome proliferator-activated receptor- $\alpha$ regulates lipid homeostasis, but is not associated with obesity: studies with congenic mouse lines. Journal of Biological Chemistry 276 39088-39093. (doi:10.1074/jbc.M107073200)

Atherton HJ, Gulston MK, Bailey NJ, Cheng KK, Zhang W, Clarke K \& Griffin JL 2009 Metabolomics of the interaction between PPAR- $\alpha$ and age in the PPAR- $\alpha$-null mouse. Molecular Systems Biology 5259. (doi:10.1038/msb.2009.18)

Benediktsson R, Lindsay RS, Noble J, Seckl JR \& Edwards CRW 1993 Glucocorticoid exposure in utero: new model for adult hypertension. Lancet 341 339-341. (doi:10.1016/0140-6736(93)90138-7)

Benediktsson R, Calder AA, Edwards CRW \& Seckl JR 1997 Placental 11ß-hydroxysteroid dehydrogenase: a key regulator of fetal glucocorticoid exposure. Clinical Endocrinology 46 161-166. (doi:10.1046/ j.1365-2265.1997.1230939.x)

Bitran D, Shiekh M \& McLeod M 1995 Anxiolytic effect of progesterone is mediated by the neurosteroid allopregnanolone at brain GABA(A) receptors. Journal of Neuroendocrinology 7 171-177. (doi:10.1111/j.13652826.1995.tb00744.x)

Boden G \& Shulman GI 2002 Free fatty acids in obesity and type 2 diabetes: defining their role in the development of insulin resistance and $\beta$-cell dysfunction. European Journal of Clinical Investigation 32(Suppl 3) 14-23. (doi:10.1046/j.1365-2362.32.s3.3.x)

Boyle KE, Canham JP, Consitt LA, Zheng D, Koves TR, Gavin TP, Holbert D, Neufer PD, Ilkayeva O, Muoio DM et al. 2011 A high-fat diet elicits http://joe.endocrinology-journals.org DOI: $10.1530 / \mathrm{JOE}-12-0540$
(C) 2013 Society for Endocrinology Printed in Great Britain 
differential responses in genes coordinating oxidative metabolism in skeletal muscle of lean and obese individuals. Journal of Clinical Endocrinology and Metabolism 96 775-781. (doi:10.1210/jc.2010-2253)

Brunton PJ \& Russell JA 2010 Prenatal social stress in the rat programmes neuroendocrine and behavioural responses to stress in the adult offspring: sex specific effects. Journal of Neuroendocrinology 22 258-271. (doi:10.1111/j.1365-2826.2010.01969.x)

Brunton PJ, McKay AJ, Ochedalski T, Piastowska A, Rebas E, Lachowicz A \& Russell JA 2009 Central opioid inhibition of neuroendocrine stress responses in pregnancy in the rat is induced by the neurosteroid allopregnanolone. Journal of Neuroscience 29 6449-6460. (doi:10.1523/ JNEUROSCI.0708-09.2009)

Cleasby ME, Kelly PA, Walker BR \& Seckl JR 2003 Programming of rat muscle and fat metabolism by in utero overexposure to glucocorticoids. Endocrinology 144 999-1007. (doi:10.1210/en.2002-220559)

Cottrell EC \& Ozanne SE 2007 Developmental programming of energy balance and the metabolic syndrome. Proceedings of the Nutrition Society 66 198-206. (doi:10.1017/S0029665107005447)

Drake AJ, Walker BR \& Seckl JR 2005 Intergenerational consequences of fetal programming by in utero exposure to glucocorticoids in rats. American Journal of Physiology. Regulatory, Integrative and Comparative Physiology 288 R34-R38. (doi:10.1152/ajpregu.00106.2004)

Drake AJ, Raubenheimer PJ, Kerrigan D, McInnes KJ, Seckl JR \& Walker BR 2010 Prenatal dexamethasone programs expression of genes in liver and adipose tissue and increased hepatic lipid accumulation but not obesity on a high-fat diet. Endocrinology 151 1581-1587. (doi:10.1210/ en.2009-1088)

Edinger KL \& Frye CA 2004 Testosterone's analgesic, anxiolytic, and cognitive-enhancing effects may be due in part to actions of its $5 \alpha$-reduced metabolites in the hippocampus. Behavioral Neuroscience 118 1352-1364. (doi:10.1037/0735-7044.118.6.1352)

Edwards CRW, Benediktsson R, Lindsay RS \& Seckl JR 1993 Dysfunction of placental glucocorticoid barrier: link between fetal environment and adult hypertension? Lancet 341 355-357. (doi:10.1016/01406736(93)90148-A)

Entringer S, Wust S, Kumsta R, Layes IM, Nelson EL, Hellhammer DH \& Wadhwa PD 2008 Prenatal psychosocial stress exposure is associated with insulin resistance in young adults. American Journal of Obstetrics and Gynecology 199 498e1-498e7. (doi:10.1016/j.ajog.2008.03.006)

Estall JL, Kahn M, Cooper MP, Fisher FM, Wu MK, Laznik D, Qu L, Cohen DE, Shulman GI \& Spiegelman BM 2009 Sensitivity of lipid metabolism and insulin signaling to genetic alterations in hepatic peroxisome proliferator-activated receptor-gamma coactivator- $1 \alpha$ expression. Diabetes 58 1499-1508. (doi:10.2337/db08-1571)

Friedman JE, Yun JS, Patel YM, McGrane MM \& Hanson RW 1993 Glucocorticoids regulate the induction of phosphoenolpyruvate carboxykinase (GTP) gene transcription during diabetes. Journal of Biological Chemistry 268 12952-12957.

Gabory A, Attig L \& Junien C 2009 Sexual dimorphism in environmental epigenetic programming. Molecular and Cellular Endocrinology 304 8-18. (doi:10.1016/j.mce.2009.02.015)

Granner D, Andreone T, Sasaki K \& Beale E 1983 Inhibition of transcription of the phosphoenolpyruvate carboxykinase gene by insulin. Nature $\mathbf{3 0 5}$ 549-551. (doi:10.1038/305549a0)

Gustafsson JA \& Stenberg A 1974 Irreversible androgenic programming at birth of microsomal and soluble rat liver enzymes active on androstene3,17 -dione and $5 \alpha$-androstane- $3 \alpha, 17 \beta$-diol. Journal of Biological Chemistry 249 711-718.

Handa RJ, Weiser MJ \& Zuloaga DG 2009 A role for the androgen metabolite, $5 \alpha$-androstane- $3 \beta, 17 \beta$-diol, in modulating oestrogen receptor $\beta$-mediated regulation of hormonal stress reactivity. Journal of Neuroendocrinology 21 351-358. (doi:10.1111/j.1365-2826. 2009.01840.x)

Hanson RW \& Reshef L 2003 Glyceroneogenesis revisited. Biochimie 85 1199-1205. (doi:10.1016/j.biochi.2003.10.022)
Harris HJ, Kotelevtsev Y, Mullins JJ, Seckl JR \& Holmes MC 2001 Intracellular regeneration of glucocorticoids by $11 \beta$-hydroxysteroid dehydrogenase (11 $\beta$-HSD)-1 plays a key role in regulation of the

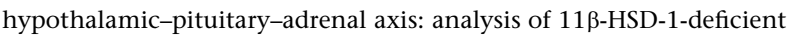
mice. Endocrinology 142 114-120. (doi:10.1210/en.142.1.114)

Huang B, Wu P, Bowker-Kinley MM \& Harris RA 2002 Regulation of pyruvate dehydrogenase kinase expression by peroxisome proliferatoractivated receptor- $\alpha$ ligands, glucocorticoids, and insulin. Diabetes 51 276-283. (doi:10.2337/diabetes.51.2.276)

Kim JY, Hickner RC, Cortright RL, Dohm GL \& Houmard JA 2000 Lipid oxidation is reduced in obese human skeletal muscle. American Journal of Physiology. Endocrinology and Metabolism 279 E1039-E1044.

Koletzko B, Symonds ME, Olsen SF, for the Early Nutrition Programming P \& Early Nutrition Academy 2011 Programming research: where are we and where do we go from here? American Journal of Clinical Nutrition 94 2036S-2043S. (doi:10.3945/ajcn.111.018903)

Kotelevtsev Y, Holmes MC, Burchell A, Houston PM, Schmoll D, Jamieson P, Best R, Brown R, Edwards CR, Seckl JR et al. 1997 11 $\beta$-Hydroxysteroid dehydrogenase type 1 knockout mice show attenuated glucocorticoidinducible responses and resist hyperglycemia on obesity or stress. PNAS 94 14924-14929. (doi:10.1073/pnas.94.26.14924)

Leone TC, Weinheimer CJ \& Kelly DP 1999 A critical role for the peroxisome proliferator-activated receptor $\alpha(\operatorname{PPAR} \alpha)$ in the cellular fasting response: the PPAR $\alpha$-null mouse as a model of fatty acid oxidation disorders. PNAS 96 7473-7478. (doi:10.1073/pnas.96. 13.7473)

Leone TC, Lehman JJ, Finck BN, Schaeffer PJ, Wende AR, Boudina S, Courtois M, Wozniak DF, Sambandam N, Bernal-Mizrachi C et al. 2005 PGC-1 $\alpha$ deficiency causes multi-system energy metabolic derangements: muscle dysfunction, abnormal weight control and hepatic steatosis. PLoS Biology 3 e101. (doi:10.1371/journal.pbio.0030101)

Lesage J, Del-Favero F, Leonhardt M, Louvart H, Maccari S, Vieau D \& Darnaudery M 2004 Prenatal stress induces intrauterine growth restriction and programmes glucose intolerance and feeding behaviour disturbances in the aged rat. Journal of Endocrinology 181 291-296. (doi:10.1677/joe.0.1810291)

Li J, Olsen J, Vestergaard M, Obel C, Kristensen JK \& Virk J 2012 Prenatal exposure to bereavement and type-2 diabetes: a Danish longitudinal population based study. PLOS ONE 7 e43508. (doi:10.1371/journal. pone.0043508)

Lindsay RS, Lindsay RM, Edwards CRW \& Seckl JR 1996a Inhibition of $11 \beta$-hydroxysteroid dehydrogenase in pregnant rats and the programming of blood pressure in the offspring. Hypertension $\mathbf{2 7}$ 1200-1204. (doi:10.1161/01.HYP.27.6.1200)

Lindsay RS, Lindsay RM, Waddell BJ \& Seckl JR 1996b Prenatal glucocorticoid exposure leads to offspring hyperglycaemia in the rat: studies with the 11 $\beta$-hydroxysteroid dehydrogenase inhibitor carbenoxolone. Diabetologia 39 1299-1305. (doi:10.1007/s001250050573)

Maccari S \& Morley-Fletcher S 2007 Effects of prenatal restraint stress on the hypothalamus-pituitary-adrenal axis and related behavioural and neurobiological alterations. Psychoneuroendocrinology 32(Suppl 1) S10-S15. (doi:10.1016/j.psyneuen.2007.06.005)

Magee TR, Han G, Cherian B, Khorram O, Ross MG \& Desai M 2008 Downregulation of transcription factor peroxisome proliferator-activated receptor in programmed hepatic lipid dysregulation and inflammation in intrauterine growth-restricted offspring. American Journal of Obstetrics and Gynecology 271 e271-e275. (doi:10.1016/j.ajog.2008.05.022)

Muoio DM, Way JM, Tanner CJ, Winegar DA, Kliewer SA, Houmard JA, Kraus WE \& Dohm GL 2002 Peroxisome proliferator-activated receptor$\alpha$ regulates fatty acid utilization in primary human skeletal muscle cells. Diabetes 51 901-909. (doi:10.2337/diabetes.51.4.901)

Nechushtan H, Benvenisty N, Brandeis R \& Reshef L 1987 Glucocorticoids control phosphoenolpyruvate carboxykinase gene expression in a tissue specific manner. Nucleic Acids Research 15 6405-6417. (doi:10.1093/nar/15.16.6405) 
Neumann ID, Kromer SA \& Bosch OJ 2005 Effects of psycho-social stress during pregnancy on neuroendocrine and behavioural parameters in lactation depend on the genetically determined stress vulnerability. Psychoneuroendocrinology 30 791-806. (doi:10.1016/j.psyneuen.2005. 03.008)

Nyirenda MJ, Lindsay RS, Kenyon CJ, Burchell A \& Seckl JR 1998 Glucocorticoid exposure in late gestation permanently programs rat hepatic phosphoenolpyruvate carboxykinase and glucocorticoid receptor expression and causes glucose intolerance in adult offspring. Journal of Clinical Investigation 101 2174-2181. (doi:10.1172/JCI1567)

Nyirenda MJ, Carter R, Tang JI, de Vries A, Schlumbohm C, Hillier SG, Streit F, Oellerich M, Armstrong VW, Fuchs E et al. 2009 Prenatal programming of metabolic syndrome in the common marmoset is associated with increased expression of 11ß-hydroxysteroid dehydrogenase type 1. Diabetes 58 2873-2879. (doi:10.2337/db09-0873)

Olswang Y, Blum B, Cassuto H, Cohen H, Biberman Y, Hanson RW \& Reshef L 2003 Glucocorticoids repress transcription of phosphoenolpyruvate carboxykinase (GTP) gene in adipocytes by inhibiting its C/EBP-mediated activation. Journal of Biological Chemistry $\mathbf{2 7 8}$ 12929-12936. (doi:10.1074/jbc.M300263200)

Ordyan NE \& Pivina SG 2005 Effects of prenatal stress on the activity of an enzyme involved in neurosteroid synthesis during the "critical period" of sexual differentiation of the brain in male rats. Neuroscience and Behavioral Physiology 35 931-935. (doi:10.1007/ s11055-005-0148-4)

Paolisso G, Tataranni PA, Foley JE, Bogardus C, Howard BV \& Ravussin E 1995 A high concentration of fasting plasma non-esterified fatty acids is a risk factor for the development of NIDDM. Diabetologia 38 1213-1217. (doi:10.1007/BF00422371)

Paris JJ, Brunton PJ, Russell JA \& Frye CA 2011 Immune stress in late pregnant rats decreases length of gestation, fecundity, and alters later cognitive and affective behaviour of surviving pre-adolescent offspring. Stress 14 652-664. (doi:10.3109/10253890.2011.628719)

Patchev VK, Hassan AHS, Holsboer F \& Almeida OFX 1996 The neurosteroid tetrahydroprogesterone attenuates the endocrine response to stress and exerts glucocorticoid-like effects on vasopressin gene transcription in the rat hypothalamus. Neuropsychopharmacology 15 533-540. (doi:10.1016/S0893-133X(96)00096-6)

Pilkis SJ \& Granner DK 1992 Molecular physiology of the regulation of hepatic gluconeogenesis and glycolysis. Annual Review of Physiology 54 885-909. (doi:10.1146/annurev.ph.54.030192.004321)

Seckl JR \& Holmes MC 2007 Mechanisms of disease: glucocorticoids, their placental metabolism and fetal 'programming' of adult pathophysiology. Nature Clinical Practice. Endocrinology \& Metabolism 3 479-488. (doi:10.1038/ncpendmet0515)
Serr J, Suh Y, Oh SA, Shin S, Kim M, Latshaw JD \& Lee K 2011 Acute upregulation of adipose triglyceride lipase and release of non-esterified fatty acids by dexamethasone in chicken adipose tissue. Lipids 46 813-820. (doi:10.1007/s11745-011-3583-8)

Tang JI, Kenyon CJ, Seckl JR \& Nyirenda MJ 2011 Prenatal overexposure to glucocorticoids programs renal 11 $\beta$-hydroxysteroid dehydrogenase type 2 expression and salt-sensitive hypertension in the rat. Journal of Hypertension 29 282-289. (doi:10.1097/HJH.0b013e328340aa18)

de Vries A, Holmes MC, Heijnis A, Seier JV, Heerden J, Louw J, Wolfe-Coote S, Meaney MJ, Levitt NS \& Seckl JR 2007 Prenatal dexamethasone exposure induces changes in nonhuman primate offspring cardiometabolic and hypothalamic-pituitary-adrenal axis function. Journal of Clinical Investigation 117 1058-1067. (doi:10.1172/JCI30982)

Welberg LAM, Seckl JR \& Holmes MC 2000 Inhibition of 11ß-hydroxysteroid dehydrogenase, the foetoplacental barrier to maternal glucocorticoids, permanently programs amygdala GR mRNA expression and anxiety-like behaviour in the offspring. European Journal of Neuroscience 12 1047-1054. (doi:10.1046/j.1460-9568.2000. 00958.x)

Welberg LAM, Seckl JR \& Holmes MC 2001 Prenatal glucocorticoid programming of brain corticosteroid receptors and corticotrophinreleasing hormone: possible implications for behaviour. Neuroscience 104 71-79. (doi:10.1016/S0306-4522(01)00065-3)

Westerbacka J, Kolak M, Kiviluoto T, Arkkila P, Siren J, Hamsten A, Fisher RM \& Yki-Jarvinen H 2007 Genes involved in fatty acid partitioning and binding, lipolysis, monocyte/macrophage recruitment, and inflammation are overexpressed in the human fatty liver of insulin-resistant subjects. Diabetes 56 2759-2765. (doi:10.2337/ db07-0156)

Yao-Borengasser A, Varma V, Coker RH, Ranganathan G, Phanavanh B, Rasouli N \& Kern PA 2011 Adipose triglyceride lipase expression in human adipose tissue and muscle. Role in insulin resistance and response to training and pioglitazone. Metabolism 60 1012-1020. (doi:10.1016/j.metabol. 2010.10.005)

Yehuda R, Bierer LM, Andrew R, Schmeidler J \& Seckl JR 2009a Enduring effects of severe developmental adversity, including nutritional deprivation, on cortisol metabolism in aging Holocaust survivors. Journal of Psychiatric Research 43 877-883. (doi:10.1016/j.jpsychires. 2008.12.003)

Yehuda R, Bierer LM, Sarapas C, Makotkine I, Andrew R \& Seckl JR 2009b Cortisol metabolic predictors of response to psychotherapy for symptoms of PTSD in survivors of the World Trade Center attacks on September 11, 2001. Psychoneuroendocrinology 34 1304-1313. (doi:10.1016/j.psyneuen.2009.03.018)

Received in final form 31 January 2013

Accepted 21 February 2013

Accepted Preprint published online 21 February 2013
(C) 2013 Society for Endocrinology Printed in Great Britain
Published by Bioscientifica Ltd. 